\title{
Hybrid Warfare: A Reorientation of Russian Foreign Policy in Syria
}

\author{
Saira Nawaz Abbasi \\ Assistant Professor \\ Cluster Head of the Faculty of International Relations \\ Department of Humanities \& Social Sciences \\ Bahria University, Islamabad Campus \\ sairanawaz.buic@bahria.edu.pk \\ Sadia Nasir \\ Ph D Candidate at the School of Politics and International Relations \\ Quaid-i-Azam University Islamabad \\ Visiting Faculty Member at the \\ Department of Humanities \& Social Sciences, \\ Bahria University Islamabad Campus. \\ sadiasnasir@gmail.com
}

\begin{abstract}
The primary focus of this research is to understand Russian hybrid warfare as a tool of Russian Foreign policy in contemporary Syria. Although hybrid warfare is not new, however Russian focus on hybrid warfare appears to signal a reorientation of its foreign policy, most visibly in Syria. Russian resurgence has caused a stir in the international community, particularly after the 'colour revolution' in Georgia in 2008. The threat seems to have grown with the Crimean Annexation of 2014 and the alleged Russian role in the U.S presidential election 2016. Russian hybrid warfare became noticeable in the Middle East, specifically in Syria after the infamous 'Arab Spring' 2011. The use of controlled warfare tactics in countering the enemy, aiding the proxies, and public opinion formation (misinformation); working aside from the governmental presentation has accelerated the international concern, as the legal uncertainties in the international law, leaves room for use of hybrid means. Consolidation of Bashar Al Assad regime, aided by Russian intervention, on the pretext of 'fighting terrorism' in 2015, also highlighted Russian resurgence in the Middle East. This research would primarily study the prospects of understanding hybrid warfare as the significant emerging generation of
\end{abstract}




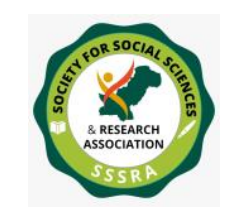

Pak. Journal of Int'L Affairs, Vol 4, Issue 2 (2021)

Hybrid Warfare: A Reorientation ...

warfare in contemporary times, understanding the nature of Russian hybrid warfare, its implication in the Middle East and in particular on Syria. The Paper will in particular look at Maskirovka - the military strategy employed by Russia, which explains its hybrid tactics and aims particularly in Syria.

Key Words: Russia, Hybrid Warfare, Syria, Middle East, Putin, Maskirovka.

\section{Introduction}

The concept of warfare evolved in modern times, despite having military capacity, is to avoid direct military confrontation. Russia has shaped its strategic intellect by learning through conflicts taking place at the regional and international level. Instead of maximising the tangible military elements, Russia kept the modern techno-advancements in the account. It devised an all-out warfare technique based on unarmed aircraft system, electronic warfare jamming equipment, spying, cyber hacking, espionage, psy-ops and propaganda. This relatively new form of warfare is named 'hybrid warfare' often, termed 'mischief tactics'.

Hybrid warfare is a complex and most debated term as various scholars and organizations are confused about its explanation. It has been practised for centuries, even before it was identified as a form of warfare in formal strategy formation. Chinese strategist Sun Tzu identified the ancient accounts of hybrid warfare in Art of War described deception tactics. He famously stated that he would compel his enemy to take his strength for weakness, and his weakness for strength and will turn his strength into weaknesses (Minford, 2008). In the Russian context, the deceptive tactics have been termed Maskirovka - a military strategy to confuse the enemy, demoralize them and uproot them from the core. It is also called the Deception Military Doctrine, which was first employed by the Russian army in 1308' Battle of Kulikov'. 'Maskirovka' was actively practised in the Soviet Union in the 1920s as the Bolsheviks overthrew the monarchy. During the World Wars, the Soviets actively employed deceptive tactics to contain and counter the axis alliance and, later on, the United States.

In the contemporary era, hybrid warfare has gained significant attention from scholars. However, it remains an ill-defined concept but broadly refers to the "use of unconventional methods as part of a multi-domain warfighting approach. These methods aim to disrupt and disable an opponent's actions without engaging in open hostilities" (Dowse and Bachmann, 2019). Frank Hoffman's phenomenal work on Hybrid warfare identifies "a range of different modes of warfare, including conventional capabilities, 


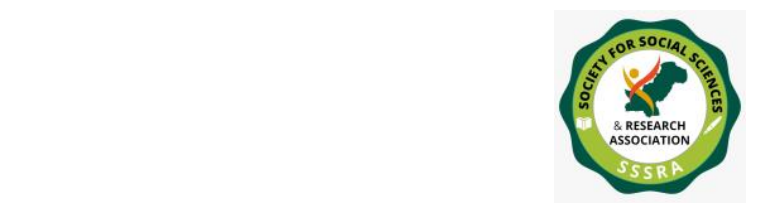

Hybrid Warfare: A Reorientation ...

irregular tactics and formations, terrorist acts including indiscriminate violence and coercion and criminal disorder" (Hoffman , 2007). States and non-state actors, both can conduct these hybrid wars. J.J Mc Cuen has defined hybrid wars as a full-throttle war involving physical and cognitive spectra regarding deceiving armed forces, controlling the region, and invoking masses against the troops. NATO has defined it as a broad tendency of overt and covert military paramilitary and civilian measures used in a crafty manner to serve the purpose (Galbreath, 2008).

Hybrid forces can easily incorporate technologically advanced systems in their force structure and strategy and use them beyond intended employment. The edge that hybrid warfare has over attrition war tact is multi-dimensional effects through various means ranging from deterring the enemy's morale to hind sighted militia attack. Further confusion invigorates as there is no proof to detain the suspect. Russian hybrid warfare caught attention during the colour revolutions in Post-Soviet territories during 20052010. The active role of Russia in the Middle East with the Arab Spring, involvement in the Syrian crisis and backing Iran in the region.

Syria has been in constant political and domestic instability for the last few decades. Russia officially engaged in the Syrian crisis in 2015 to primarily defend the Bashar Al Asad regime but intervened under the hoax of 'fighting terrorism by confronting ISIS'. Russia intervened with air operations from the Kheimeim base to attack the rebels, deploying PMC (Private Military Companies) in Syria, even though these PMCs were banned in Russia, while ostensibly declaring the main agenda to be counter-terrorism in Syria by eliminating ISIS. However, this rhetoric is contradictory to the ongoing Syrian crisis, thus implying the strengthening of Bashar Al Asad's regime as the primary purpose of Russian intervention. Another reason for Putin's support for Assad's government is due to the port of Tartus in northern Syria. Putin plans on creating an economic corridor that brings oil from Iran and Iraq to Syria at the port of Tartus and thereon to Europe. The Russian involvement in Syria appears to have several hidden purposes. From testing the Russian military strength in new arenas to gaining power acknowledgement from regional neighbours. Russia has gained credibility in the Middle East, and its neighbourhood is evident with the improvement in relations with Turkey, Saudi Arabia, Egypt and Iran. Moreover, the continued competition between Saudi Arabia and Iran provides Russian with avenues to sell its ammunition in the region and creating a route for its economy (Canadian Forces College, 2017).

\section{Theoretical Understanding of Russian Hybrid Warfare}




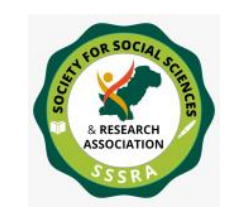

Hybrid Warfare: A Reorientation ...

The research bases its theoretical underpinning on 'Maneuver theory' for understanding hybrid warfare techniques employed by the Russian regime in the contemporary era, specifically under Putin's leadership. This theory considers warfare beyond the conventional set of tactics and strategies and its crafty essence in defeating the enemy's will to fight, shattering the morale of the enemy rather than his ability to fight back (Freedman, 2013). Manoeuvre theory emphasizes human centrality in warfare. It relies on agility, deception, the element of surprise and the application of firepower and movement. Importantly, manoeuvre theory considers war as a competition based on time and space rather than the spatial position alone. The ability to retain high momentum of operations relative to enemies creates opportunities to defeat their centre of gravity, that is, to uproot their organization. Manoeuvre theory is based on a profound psychological understanding of one's enemy and ways to challenge their strengths. The theory also accounts for friendly forces and the neutral and non-combatant parties within and outside the battlefield. Liddell Hart's explanation is pertinent to understand the essence of the theory, when he says, "The perfection of strategy would ... be to produce a decision - the destruction of the enemy's armed forces through their unarming and surrender - without any fighting"( Hagelkvist, 2015).

For the better implementation of this theory in terms of warfare and military strategies, a synonymous derivation is 'Maneuverist approach' that 'seeks to shatter the enemy's cohesion through series of actions orchestrated to a single purpose, creating a turbulent and rapidly deteriorating situation with which enemy cannot cope' (Lauer, 1991). Maneuverist approach is applicable at all levels of warfare. At the Strategic level, coordinated application of all the elements of national power is directed to achieve the national objective as set by the state. At the Operational level, manoeuvre tends to place forces using offensive, defensive and deceptive techniques according to the enemy position. The Tactical Level employs physical or non-physical means to achieve a relative edge over the opponent to accomplish the assigned task. The sole purpose of the tactical manoeuvre is to destroy the enemy's unity through shock, surprise and lethal force. This mix of conventional and non-conventional strategies to achieve the interest signifies the tactical level.

Russian hybrid warfare can be understood by applying manoeuvre theory, but the practical demonstration of Russian tactics is well described by the Soviet's military doctrine called Maskirovka, which means 'masking' and as a tactic implies 'misrepresentation' (Elliott, 2018). Maskirovka is a traditional Russian use of military deception that bases its formulation in an exaggerated show of military might to the enemy, to keep the enemy guessing of the next move and to create confusion by an articulated flow of wrong information. As analyst Julian Lindley French said, 'It's 


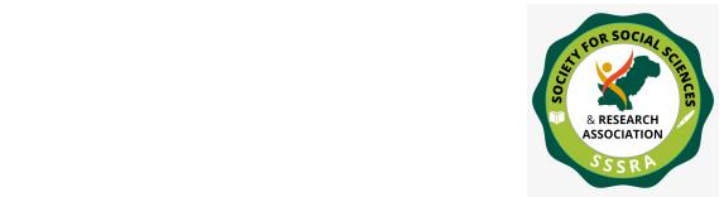

Hybrid Warfare: A Reorientation ...

designed, quite simply, to keep adversaries permanently off-balance, guessing what Moscow really intends' (French, 2018). Under Putin's leadership, strategic Maskirovka ambitions have unearthed in the advent of recent events that have caught Western attention to deceptive manipulation on Russian's behalf. These events include the annexation of Crimea (2014), the incursion of East Ukraine, the Russian backing of Bashar Al Asad regime in Syria by proper military deployments, interference in the U.S. election 2016.

With resuming office for the third time in 2012, Putin has embarked on an increasingly aggressive and anti-Western foreign policy and security policy by literally abandoning partnership with the West. This strategy reflects Putin's ambitions and perspective of world view, particularly his belief that the West has failed to regulate international politics. Putin's regime aims to uproot the U.S. influence in the Middle East, thus reestablishing itself and pushing the U.S. back to its borders.

\section{Nature Of Russian Hybrid Warfare Post Arab Spring}

Hybrid warfare for Kremlin has been the use of a broad range of overt techniques of nonmilitary instruments to secure Russian interests in the region. In contemporary times, it is noticed that Russian hybrid strategies have usually revolved around techno-deception. It may be deduced here that the primary objective of Russian hybrid warfare aims to uproot and weaken NATO's control in former Soviet territories and region in proximity i.e. the Middle East and revert the pro-western governments by lobbying or propaganda. It also aims at annexing territories (primarily under the context of greater Russia) and finally accessing European markets on its terms. Russian hybrid warfare appears to have three main characteristics as identified by Chivvis (Chivvis, 2017). Firstly, it economizes the use of force as the main reliance is on other means such as cyber tools. Secondly, it is persistent since unlike conventional war there is no delineation between war and peace. And thirdly, it is a population-centric approach that tends to influence the public through information management and proxy groups.

The essential tenets of Russian hybrid warfare revolve around capturing territories without using conventional military interference, as seen in Crimean annexation 2014. It alarmed the world of Russian ambitions, the well-known covert technique of using 'little green men' an elite group of forces deployed in the respective region, manipulated the information system and annexed Crimea in a bloodless manner. A similar pattern was evident during the invasion of Georgia (Bachmann and Paphiti, 2016). The resulting 'frozen conflict' of Ukraine and Georgia have hindered their efforts to integrate with Western Europe. Russia has experimented with these grey zone techniques in proximity 


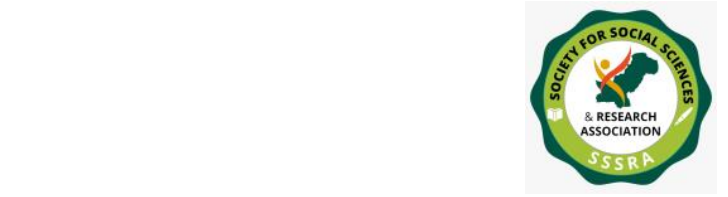

Hybrid Warfare: A Reorientation ...

to ensure concrete results. In the 2013 modern warfare document of Russian Chief of General Staff, Gen. Valery Gerasimov acknowledged the use of non-military methods in contemporary conflicts as being four times more than the military methods for Russia (Andrew, 2015). His ideas influenced Russian doctrinal thinking and were termed the "Gerasimov Doctrine"( Bachmann and Paphiti, 2016). In this context, it needs to be pointed out that Russian hybrid warfare includes creating pretext through cyber propaganda to justify overt and conventional military intervention.

Russia also streamlined the decision-making process in hybrid warfare by setting up the National Defense Management Centre (NTsUO) in 2014. This body coordinates the activities, not just of military structures, but also of security and civilian agencies such as the Federal Security Service (FSB), the Federal Protective Service (FSO), the Foreign Intelligence Service (SVR), the Ministry of Interior, and State Atomic Energy Corporation Rosatom. The centre is seen to have "an incredibly expansive list of oversight, monitoring, and decision-making functions for state defence." According to Russia expert Roger McDermott, the NTsUO represents a step "toward conducting more integrated security operations in the future." The body is designed to give Russia the edge over NATO in taking decisions in a shorter time frame. Simultaneously, other hybrid techniques in Russia's arsenal are intended to sow discord among and within NATO allies to slow down NATO decision-making.

Hybrid warfare does not refer solely to non-kinetic operations. Experts note that, as part of its hybrid tactics, Russia has employed "a full spectrum of activities, ranging from incitement of violence, kidnapping, and attempted assassination to infiltration and covert action combined with military efforts"( Kramer and Speranza, 2017). The most obvious example of a kinetic operation is the use of professional soldiers without military insignia, likely Russian Special Forces, charging up for the occupation of Donbas and Crimea.

\section{Gerasimov Doctrine and Hybrid Warfare In The Middle East}

Gerasimov Doctrine is a reflection of Russian interests contesting in relative order with other states. Thought the tactics of Hybrid warfare in Russian policymaking had dated back to Soviet times. Still, in the contemporary era, the new term of Russian tactics has caught attention as it redefines the nature of warfare. The Russian General Valery Gerasimov reflected his analysis on the need of changing the warfare dynamics in his article, 'The value of Science insight' 2013. The article narrates the lessons learnt from the Arab Spring 2011 and the altercation of a world order where the role and execution of command through militaries have been upgraded to more cyber and techno-based action. 


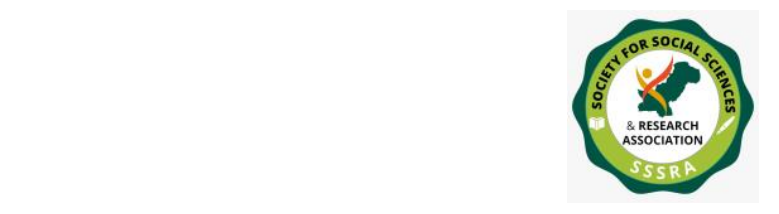

Hybrid Warfare: A Reorientation ...

Geopolitics has always played an important role in Russian strategic policy formation; thus, Gerasimov declared the need for Russian intervention in the unstable and politically conflictual territories, especially with whom Russia shares borders and have strategic interests. In this doctrine, the case study of Arab Spring is illustrated by highlighting the need for control over information spread and information bots. He also noted the importance of mercenary military companies used in close coordination with regular armies. Though carrying a complete analysis on the spread of Arab Spring, Gerasimov pointed the problematic U.S. presence in the Middle East while also pointing out the need for a covert operation in politically unstable regions (Bartles, 2016). In light of Russia's current political and strategic ideology, it can be stated that after the quick test of hybrid/cyber warfare tactics in Ukraine and the Baltic region, Russia is aligning its comeback in the Middle East. It is important to highlight that Russia opted to manoeuvre Eastern Europe and the Middle East simultaneously. Russia played a buffer role during the Arab Spring and made an official intervention during the Syrian Civil War.

\section{Russian Reaction to Arab Spring}

Russia, especially under Putin, has tried to regain its influence in the Middle East which it enjoyed under the Soviet Union. Putin's efforts became eminent in shaping political interest towards West Asia with the Arab Spring of 2011. The historical demonstrations, sparked by Mohamed Bouazizi's suicide due to police corruption in Tunisia in 2010, spread the protests throughout the MENA region. The vibrant spread alarmed the world when all major countries like Egypt, Libya, Morocco, Syria, Bahrain, Yemen, and Jordan witnessed similar street uprising. Carnegie centre on analysis over Arab spring mentioned that it was not retaliation to the economic needs of the masses as Libya and Egypt were prosperous under their dictatorial rule. Instead, it was more of the rise of a new generation raised under the globalized era who blatantly rejected the hold of dictators in political positions. Moscow has tried in several conflicts to act as a mediator to stabilize the Middle East, such as failed mediation to prevent the U.S. invasion of Iraq in 2003 toppling of Saddam Hussein and to overthrow Moammar Gaddafi in Libya. Both being allied with Moscow (Dannreuther, 2015). Russia officially intervened in Syria on 30 September 2015, taking many by surprise, but it was a way to ensure that the Arab Spring stops its domino effect in the region. Russia made sure not to lose its ally in the Middle East by halting the Arab revolution.

\section{Russian Hybrid Warfare in Syria}




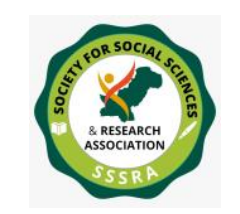

Hybrid Warfare: A Reorientation ...

With the spread of Arab Spring to Syria, Moscow and the West stood against each other regarding their reaction to opposition against Bashar Al Assad. Despite severe opposition, the Assad regime continued. In 2011, President Medvedev made it clear that Russia would veto any sanctions against Syria by U.N. Security Council. Later, Foreign Minister Lavrov warned the international community against using the Syrian crisis for provoking Russia, representing the importance of Syria for Russia. The Syrian civil war has been responsible for human suffering and carnage, with 6.6 million refugees and about 6.2 million displaced within the country due to this conflict (World Vision International, 2021). This crisis has invited regional actors and non-state entities, and international actors to deploy their troops and proxies in the region. It has to be noted that after the Arab Spring, especially with NATO's invasion of Libya and stripping Moammar Gaddafi from the seat, it was seen as a betrayal and threat by the Russians. With the similar expected fate of Syria, Russian jumped into support of Bashar Al Asad's regime, declaring it a legitimate entity in Syria. Along with all this political upheaval, Russia devised the Gerasimov doctrine (2013) to methodological act in its regional proximity with altered and improved foreign policy (Cordesman, 2015).

It needs to be reiterated here that the concept of hybrid warfare or shadow politics emerged in the Middle East with the onset of Arab Spring as the leaders ruling for decades feared the overwhelming support for the street uprising. Thus, the popular uprising was politicized to paint a common enemy and strengthen their hold. In light of this, Bashar Al Asad responded with a brutal crackdown over the non-violent protest movement and murdering the young graffiti artist in 2012. The events opened Pandora's box of severe ethnic and sectarian violence and responded with force by the Asad's regime. By 2013, Damascus was under fierce attack by rebels supported by the Sunni majority. Assaults by secular and Islamists supported by Western powers such as the USA, UK, France, Turkey and Arab Gulf states complicated the interests in conflict.

Amid the conflict, the Syrian regime was supported through critical weapons, manpower and military by Iran, Hezbollah and Russia to curb the rebellion. Despite all assistance, the government faced severe human resources shortages. By summer 2015, rebels took over Latakia, Idlib and Hama. Russia officially intervened in Syrian territory by promoting the rhetoric to fight against terrorism and filling up the power vacuum created by the U.S. withdrawal from the region. Unlike the popular Western concept of hybrid warfare, Russian hybrid wars include the use of conventional forces along with nonconventional ones. In the Syrian context, Russian Air Force aircraft constitute significant means of manipulating the conflict along with the Russian Army Military Police and Special Forces (SPETSNAZ) troops (Clark, 2020). Russia started with the airstrike against the rebels, hoping to prevent the regime from overthrowing Russia's deployed 


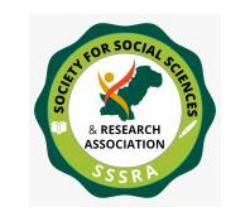

Hybrid Warfare: A Reorientation ...

armed forces in Syria. Russia hybridism onset can be observed as Putin championed the international platform by declaring their fight against the rise of Islamic militancy, a narrative that also portrayed Western interests. This narrative allowed Russians to intervene in the Syrian civil crisis, but Putin's regional interests were not limited to containing Islamism. Moscow aimed to fortify Assad's regime to strengthen the RussianIranian-Shiite cooperation forming an alliance, which threatened the U.S. interests in the region. It is stated that it was part of Syrian policy to resurge the Russian presence in the Mediterranean and countering the U.S. regional dominance. Along with all this, Russia aimed at keeping the Russian born Islamic terrorists in Syria rather than allowing them back in Russia and preserving their historical control over the port Tartus (Cordesman, 2015).

It is to be noted that the Russian gamble in Syria proved to be a fruitful test for the Russian hybrid warfare under the Gerasimov Doctrine 2013. Kremlin played a low profile role under the cloak of anti-terrorism. Primarily, Russian involvement has been attributed to mercenaries and the volunteers who fought for the cause. Amid the civil war, Syria ensured Russia that it remains the viable strategic partner in the region. Russia deployed its ships to Syria in 2011 and 2012 to show its support for the Assad regime (Cordesman, 2015). Kremlin has claimed to benefit from the oil and gas development and reconstruction projects in post-civil war Syria. Its Tartus port allows access to warm waters. Syria leased Tartus port for 49 years to Russia in 2017, reflecting Kremlin's strong foothold in Syria.

Using the Russian success in Syria, Kremlin aims to develop military ties with the Egyptian government and explore access to deep water ports in Libya and gain a foothold in the country (Hoffman, 2016). In the aftermath of the Russian resurgence, Russian hybrid techniques have been named brutal campaigns involving disinformation and propaganda. Kremlin used the counter-terror policy against I.S. to gain strategic alleviation from the political situation. Though the Russian supported the Asad's regime to dislodge I.S. from the region of Deir er Zor, the bombings also targeted secular and Islamist not affiliated with I.S. It has supported the regime's efforts to starve, bomb and bludgeon opposition forces into submission. The disinformation campaigns deny the killing of civilians labelling the accusations propaganda, thus infuriating the whole scenario. Putin's diplomacy has also helped the proceeding of war and respective intervention (Chivvis, 2017). Russian mercenaries deployed in Syria are supporting Hezbollah's offshoot groups active in Syria. Russia has shared the hybrid war in its coordination with the Iranian militias. The Russian military has successfully complemented Iran's and Hezbollah's contributions (International Crisis Group, 2017). 


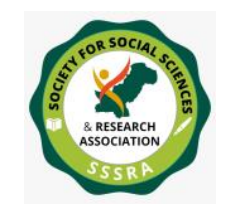

Hybrid Warfare: A Reorientation ...

Kremlin has improvised its hybrid techniques through proper articulation, monetarily supported, and coherent strategy. Kremlin's intention to use hybrid tactics has been documented. The first one was the Military Doctrine (2014), National Security Strategy (2015), and finally, the Information Security Doctrine (2015). The main crux of these document has to been to influence and shape the masses opinion within borders or abroad in favour of the Russian narrative. Thus Russia has been using non-traditional methods to achieve this perspective building. In his famous article where tenets of hybrid warfare are mentioned, Russia's Chief of General Staff Valery Gerasimov pointed out, that "information space opens wide asymmetrical possibilities for reducing the fighting potential of the enemy" (NATO StratCom, 2015). In February 2017, Defense Minister Sergey Shoigu publicly announced the creation of information operations forces "for counter-propaganda purposes"(Wither, 2016).

Within Syria, Russian continued military involvement after the formal withdrawal of Russian forces is even more mysterious and has relied on a private paramilitary company, the Wagner Group, associated with a Russian oligarch, Yevgeny Prigozhin. The clash of these trained Russian mercenaries with the U.S. forces in Syria resulted in the deaths of about 100 Russian mercenaries (Canadian Forces College, 2017). Such a direct clash between Russian and American soldiers is unprecedented in recent history and could have resulted in a dangerous escalation. However, Putin was able to deny any links between the Russian state and these mercenaries.

Russia uses cyber weapons to carry out hybrid operations such as election meddling, espionage and disinformation campaigns. 2017 saw large-scale cyber-attacks against critical infrastructure with severe real-world consequences. Russia is also suspected of carrying out electronic warfare (E.W.) attacks. The former commander of United States Army Europe, Gen. Ben Hodges, notes that Russia has improvised "a significant electronic warfare capability" during the last three years (Jopling, 2018). On the eve of the Zapad 2017 exercise, the mobile communications network in western Latvia was jammed, apparently by a Kaliningrad-based communications jammer aimed towards Sweden. A NATO official claimed the incident demonstrates Russia's ability to intercept or obstruct civilian networks "within a significant radius and with relative ease"(Jopling, 2018).

Russia intends to start a venture for hydrocarbon exploration in the Arctic Region to maintain its monopoly of oil and gas and use it against other countries (The Arctic: A New Battlefield for US-Russia Rivalry, 2021). It is believed that when the civil crisis in Syria ends, Russia along with other major players in the energy market such as Iran, Syria and Qatar, will export over one-third of the world's gas. This will be a direct threat 


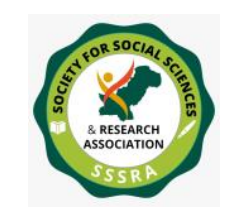

Hybrid Warfare: A Reorientation ...

to the United States, as gas and oil will be the tool used to exploit many U.S allies. The next ten years will be a challenge for the U.S as Russia, and the Middle Eastern states are thought to agree on many energy issues. The traditional alliances in the region have broken, which have led to Russia becoming a major player (Krasik and Blank, 2018). Through economic ties, the Kremlin uses its divide and conquer policy by working with its former energy rivals in the region.

\section{Conclusion}

Well, the primary focus has been to elaborate and predict the nature of Russian hybrid warfare, understanding its execution in a basic manner starting from the Russian security policy of Maskirvoka to modern-day up-gradation to Gerasimov Doctrine. The whole narration is in respect of the Maneuverist approach's tenet of strategic level that aims at inciting disinformation in such a manner that the masses support the interest of the actor. The Russian hybrid warfare is the depiction of such deceptive measures ranging from Crimean annexation to the Syrian civil war. Moreover, an educated guess has been made over the dire rise of hybrid tactics in the contemporary era specifically in the context of the Middle East. The resurgence of Russia under the 'Deception Doctrine' is a new interest for scholars whilst alarming the western liberal ideology. The nature of hybrid warfare is discreet and non-conventional in its execution thus making it hard to comprehend with a lingering uncertainty of the tactics. Russian hybrid warfare coupled with modern-day scientific advancement has threatened the international community over the perception of counter-response.

Then, the whole threat of Russian hybrid warfare is discussed with an area study of the Middle East. A thorough understanding has been developed in light of the Manueverist Approach's second postulate stating the operational level execution of hybridism in warfare. This level of analysis illustrates the Russian discreet tactics in the Syrian civil war that has left NATO baffled over the requisite response. NATO struggling with this threat primarily because of its undecipherable nature. NATO lacks the intent to invoke article 5 of the Washington Treaty that demands a unified response to neutralize the threat if one member is under attack. The whole chuck o literature discusses how Russian tactics have threatened the U.S dominance in the Middle East by simultaneously engaging in Eastern Europe and the Middle East.

Lastly, Russian renewed foreign policy in light of the 'Gerasimov Doctrine' has been comprehended. Politics, economics and strategic alliances are a depiction of hybrid warfare as well. In this research under the last postulate of the Maneuverist Approach, the Tactical level that aims at using full-blown hybrid engagement with the enemy is used to 
predict Putin's ambitions towards the Middle East. As speculated by certain foreign policy steps taken by Putin in recent times especially towards the Middle East, his whole shift of 'Pivot towards West Asia'. Russia has made an impressive comeback in the Middle East after forty years and has been able to establish itself as the most important regional superpower. This time it has to be considered that Russia is formulating such foreign policy based on nuclear denigration and energy-based policies that will ensure that Russia has a strong physical presence in the Middle East, something that cannot be challenged by Arabs in coming altercation towards their diplomatic conduct. It can be concluded that the discreet foreign conduct by Russians is signifying a bombastic comeback in the international arena and hence, a dire question to U.S supremacy in the region. 


\section{References}

Bachmann, S. D. D., \& Papithi, A. (2016). Russia's hybrid war and its implications for defence and security in the United Kingdom. Scientia Militaria: South African Journal of Military Studies, 44(2), 28-67.

Bartles, C. K. (2016). Getting gerasimov right. Military Review, 96(1), 30-38.

Blank, S. (2018). Russia In the Middle East. T. Karasik (Ed.). Retrieved from https://jamestown.org/wp-content/uploads/2018/12/Russia-in-the-Middle-Eastonline.pdf?x87069

Canadian Forces College, M. (2017). Russian Hyrbrid Warfare in Syria: Air Force, Private Military Contractors and Dis-information. Reterived from Canadian Forces College website: https://www.cfc.forces.gc.ca/259/290/402/305/vanvolkenburg.pdf.

Chivvis, C. S. (2017). Understanding Russian "Hybrid Warfare". Rand Corporation.

Clark, M. (2020). Russian Hybrid Warfare.

Cordesman, A. H. (2015). Russia in Syria: Hybrid political warfare. Center for Strategic and International Studies.

Dannreuther, R. (2015). Russia and the Arab Spring: supporting the counterrevolution. Journal of European Integration, 37(1), 77-94.

Elliott, J.K. (2018, June 9). Theatrically and deception: How Russia uses 'maskirovka' to shake the world. Global News. Retrieved from https://globalnews.ca/news/4260938/russia-strategy-maskirovka-military-politicsputin/

Freedman, L. (2013). Strategy: a History Oxford.

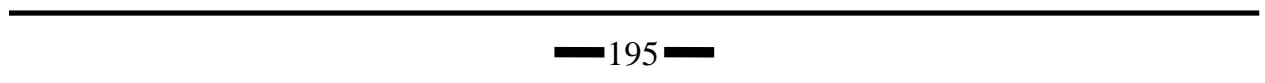


Galbreath, D. J. (2008). Putin's Russia and the 'New Cold War': interpreting myth and reality. Europe-Asia Studies, 60(9), 1623-1630.

Hagelkvist, A. (2015). Theories of warfare: French operations in Indo-China.

Hoffman, F. G. (2007). Conflict in the 21st century: The rise of hybrid wars (p. 51). Arlington: Potomac Institute for Policy Studies.

Hoffman, F. G. (2016). The contemporary spectrum of conflict: protracted, gray zone, ambiguous, and hybrid modes of war. The Heritage Foundation, 25-36.

Jopling, L. (2018). Countering Russia's hybrid threats: an update. NATO Parliamentary Assembly.

Kramer, F. D., \& Speranza, L. (2017). Meeting the Russian hybrid challenge: A comprehensive strategic framework. Atlantic Council.

Lauer, G. S. (1991). Maneuver warfare theory and the operational level of war: Misguiding the Marine Corps?. Army Command and General Staff Coll Fort Leavenworth KS School of Advanced Military Studies.

Lindley-French, J. (2015). NATO: Countering Strategic Maskirovka. Canadian Defence \& Foreign Affairs Institute.

(March, 2017). International Crisis Group. Brussles, Belgium. Retrieved from https://www.crisisgroup.org/middle-east-north-africa/easternmediterranean/lebanon/175-hizbollah-s-syria-conundrum

(n.d.). The Conversation, June 17, 2019. Retrieved June 19, 2021, from https://theconversation.com/explainer-what-is-hybrid-warfare-and-what-is-meantby-the-grey-zone- 118841

Peco, M. (2018). On" The'War'in Russia's' Hybrid Warfare'". Parameters, 48(1), 111.

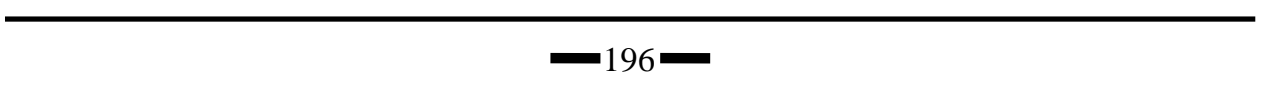


The Arctic: A New Battlefield for US-Russia Rivalry. (2021, May 18). TRT World.

(2008). "Waging War." In The Art of War, translated by Lionel Giles, 71-75. North Clarendon, USA: Tuttle Publishing.

Wither, J. K. (2016). Making sense of hybrid warfare. Connections, 15(2), 73-87.

World Vision International. (2020, June 11). Syrian Refugee Crisis: Facts. FAQs, and How to Help. Retrieved from https://www.worldvision.org/refugees-newsstories/syrian-refugee-crisis-facts. 